\title{
O lugar da Teoria literária
}

\author{
Luiz Fernando Martins de Lima
}

Cechinel, André (org.). O lugar da Teoria literária. Florianópolis: UFSC, 2016, 439

p., contribuições de Alamir Aquino Corrêa, Alckmar Luiz dos Santos, Aline Magalhães Pinto, André Cechinel, Cristiano de Sales, Dalva de Souza Lobo, Eduardo Subirats, Eneida Maria de Souza, Fabio Akcelrud Durão, Flavia Trocoli, Ivete Walty, Jonathan Culler, Luiz Costa Lima, Márcio Seligmann-Silva, Maria da Glória Bordini, Nabil Araújo, Paulo Franchetti, Peter Barry, Regina Zilberman e Sérgio Luiz Prado Bellei.

Coletânea de vinte artigos organizada por André Cechinel, professor da Universidade do Extremo Sul Catarinense (Unesc), O lugar da Teoria literária surge a partir de uma ementa proposta aos autores convidados - figuras basilares, de hoje e de ontem, da crítica literária brasileira e estrangeira -, a qual vale a pena citar na íntegra para o início da presente discussão:

Em 2003, a partir de uma conferência organizada em torno de nomes como Jacques Derrida, Frank Kermode, Toril Moi e Christopher Norris, Michael Payne e John Schad publicam o livro Life. After. Theory, cujo intuito é, em linhas gerais, "discutir se a coruja de Minerva, o pássaro da teoria, foi finalmente abatida, se ela está desgastada como um albatroz morto, ou se então se lança a um último voo, tardio e glorioso". Ora, mais que um tratado sobre a chamada crise da teoria, o livro pode ser visto como sintoma de um problema que, ao longo da última década, foi repetidas vezes diagnosticado [...]. No Brasil, também voltada ao problema particular da "teorização em um país periférico", como indica o subtítulo de um dos livros recentes de Luiz Costa Lima, a questão da crise da teoria não deixou de preocupar teóricos como Eneida Maria de Souza, Leyla Perrone-Moisés e o próprio Luiz Costa Lima, apenas para citar alguns exemplos. Inserido nessa discussão, o presente livro, intitulado O lugar da Teoria literária, propõe-se a reunir trabalhos que problematizem justamente o espaço ocupado pela teoria literária como disciplina acadêmica num momento dominado pelo discurso da suposta crise da teoria. (p. 9). 
Cechinel, a rigor, se refere especificamente a uma problemática das letras norte-americanas que migrou para o Brasil, como tantos são os fenômenos acadêmicos de lá que seguem o mesmo percurso. Essa problemática possui raízes históricas na década de 1960, quando um influxo de filosofia continental penetrou os estudos literários norte-americanos. A hermenêutica heideggeriana, via Gadamer e especialmente Iser, a desconstrução, de Derrida, o historicismo foucaultiano, entre outras correntes, configuraram novas preocupações intelectuais, regidas especialmente por um ultra ceticismo, de modo que temos as famosas "crises" da figura do autor, da possibilidade da leitura, das construções ideológicas etc. Como afirma um dos autores da coletânea, o professor Bellei, da UFMG, dificilmente seria possível a criação de categorias que englobassem todos os movimentos da chamada Teoria com $t$ maiúsculo, como ficou conhecido esse fenômeno acadêmico de traços estadunidenses, embora fosse possível entendê-las pela clave da "hermenêutica da suspeita", em suma, um ceticismo kantiano, se não pírrico. Essa história tem vários capítulos, como a queda de Paul de Man, principal pupilo de Derrida nos Estados Unidos, em decorrência da descoberta, na década de 1980, de seus escritos antissemitas de juventude - o que justificaria a sua obsessão pela ideia de arbitrariedade da narrativa histórica, a qual isentaria seu passado; a publicação da segunda edição da Norton Anthology of Theory and Criticism (2001, 2010), tendo como editor geral aquele que talvez seja o maior apologista da Teoria nos Estados Unidos, o professor Vincent B. Leitch, da Universidade de Oklahoma, que, juntamente com seus colaboradores, em seu processo de escolha dos contemplados, excluiu figuras tradicionalíssimas que constavam na primeira edição, como Quintiliano, em prol de nomes da moda, como N. Katherine Hayles e seu moderníssimo conceito de "pós-humano"; e, nesse ínterim, a publicação do ataque mais veemente à Teoria até então registrado, Theory's Empire (2005), organizado por Daphne Patai e Wilfrido Corral, marco fundamental da chamada "crise da teoria" mencionada por Cechinel. Desde a ascensão da Teoria, na década de 1960, lá se foi meio século.

Diante desse brevíssimo histórico, é possível vislumbrar o grande problema de O lugar da Teoria literária: a Teoria, no Brasil, não está em crise, e os três últimos ensaios do próprio livro (assinados por Alamir Aquino Corrêa, Regina Zilberman e Paulo Franchetti), com todos os dados e testemunhos apresentados, são prova cabal de que, pelo contrário, a Teoria está no auge, é hegemônica, e as contestações a sua hegemonia começaram faz poucos anos. Como demonstra a professora Regina Zilberman, da UFRGS, ela já penetrou o contexto do Ensino Médio, regendo as questões de exames nacionais padronizados, como o Enem. Segundo Paulo Franchetti, hoje predomina o 
caráter autorreferencial da Teoria, cujos praticantes desenvolvem textos que se referem a outros textos dentro da mesma corrente, de modo que os ensaios se assemelham a fórmulas matemáticas:

A chamada Teoria é uma resposta eficiente à demanda produtivista e à perda de importância da literatura no conjunto dos conhecimentos universitários. [...] a real vantagem da Teoria é que ela permite gerar uma profusão de textos que se comentam entre si e que se destinam à comunidade de autores da própria Teoria. A moda, portanto, não tem pequena importância na definição seja dos temas, seja da linguagem. E a postura típica do "teórico" é falar sobre um objeto a partir de um ensaio de um autor em alta, de última moda, ou partir de uma ou outra metáfora que se descubra no objeto ou se recolha de autor reconhecido no campo da Teoria (p. 431).

Tal postura, excessivamente abstrata e conceitual - a ponto de conceitos se referirem tão somente a outros conceitos -, é atacada por outros autores da coletânea, como Eduardo Subirats, da Universidade de Nova York, Peter Barry, da Aberystwyth University, e André Cechinel.

Ao mesmo tempo, temos o ensaio do professor Sérgio Bellei, que, de lança em riste, sai em defesa da Teoria, especialmente nas figuras de Derrida, Foucault e Barthes, e ataca Auerbach, Gombrich, Popper e Wellek, o que, às vezes, causa a estranha sensação de o ensaio ter sido escrito na década de 1960, em uma era pré-Teoria.

Assim, O lugar da Teoria literária, embora parta de uma premissa que, no Brasil, queima etapas, possui valor exatamente na pluralidade de ensaios que apresenta, ou seja, não é em si, como o Theory's Empire, um ataque à crise da Teoria, nem uma defesa dela.

Uma passada rápida de olhos dá a impressão de que muitos autores não responderam especificamente à ementa proposta. Tomemos como exemplo o ensaio da professora Maria da Glória Bordini, em que faz um recenseamento das grandes teorias da lírica, desde Platão, passando por Hegel e chegando ao século xx com Adorno e Dufrenne. Embora exemplar, o ensaio não se refere explicitamente à crise da Teoria. Nas entrelinhas, contudo, temos uma manifestação hostil à Teoria, explicitada em breve momento ao final do ensaio: "O poético, se nesses dias de incerteza e relativismo pós-modernos continua enigmático, resiste nas criações dos poetas e na apreensão dos leitores de poesia" (p. 289, grifos meus). Esse "relativismo pós-moderno" é outra expressão que diz respeito ao ultraceticismo da Teoria, já que, às vezes, Teoria e Pós-modernismo são usados de maneira intercambiável, e o ensaio da professora Bordini é uma tentativa de 
valorizar aqueles que, na história das ideias sobre a poesia, fizeram genuíno esforço de apreender sua essência, embora em muito esta tarefa possa ser impossível.

Em outros exemplos, temos a presentificação daquilo que é atacado por Franchetti no ensaio supracitado, ou seja, uma excessiva carga conceitual desprovida de balizas concretas. O exemplo mais evidente é o ensaio da professora Dalva de Souza Lobo, da Universidade Federal de Lavras, acerca da voz. Não está claro no ensaio a que essa voz se refere. Sabe-se que ela é "plural", em oposição à escrita, que é "fixa", segundo Zumthor. No entanto, essa voz pode se manifestar em romances, assim como em obras vanguardistas de apresentação oral de poesia lida coletivamente. É regida pela ideia de rizoma, de Deleuze e Guattari, assim como de bricolage, de Levi-Strauss, e de índice, de Peirce, entre vários outros. É um exemplar prototípico de um texto nos modelos propostos pela Teoria.

Por fim, temos a posição apaziguadora do professor Fábio Alckerud Durão, da Unicamp, que abre o volume buscando, num movimento diplomático, conciliar as diferenças de modo a não jogar fora o bebê com a água do banho, destacando a importância da Teoria em aspectos que, segundo Durão, precisam ser valorizados, como o seu papel no questionamento e reformulação dos valores estéticos (p. 24).

A organização dos ensaios não é ideal e pode atrapalhar um leitor que esteja sendo introduzido à questão. No entanto, sua pluralidade de posições e de exemplos prototípicos de formas diferentes de escrever sobre literatura - desde um conservador recenseamento crítico até a exploração infinitamente conceitual à la Derrida, nas mãos de um professor ciente do histórico da problemática, que redefiniria a ordem dos ensaios - o torna um volume valioso e sem igual publicado no Brasil, já que poderia ser lido quase por completo em um hipotético curso de pós-graduação acerca do tema.

Luiz Fernando Martins de Lima é Professor Substituto do Departamento de Literatura da Universidade do Estado de São Paulo/Campus de Assis 